\title{
Effects of a novel co-culture system on development, metabolism and gene expression of bovine embryos produced in vitro
}

\author{
S. Rief ${ }^{*}$, F. Sinowatz ${ }^{2}$, M. Stojkovic ${ }^{1}$, R. Einspanier ${ }^{3}$, E. Wolf ${ }^{1}$ and K. Prelle ${ }^{1+}$ \\ ${ }^{1}$ Department of Molecular Animal Breeding and Biotechnology, \\ Ludwig-Maximilian University Munich, Hackerstr. 27, D-85764 Oberschleissheim, \\ Germany; ${ }^{2}$ Department of Anatomy II, Ludwig-Maximilian University Munich, \\ D-80539 Munich, Germany; and ${ }^{3}$ Department of Physiology, \\ Technical University Munich-Weihenstephan, D-85350 Freising, Germany
}

An in vitro model using co-culture of bovine in vitroproduced (IVP) embryos and bovine oviduct epithelial cells (bOECs) was established to study embryo-maternal interactions in the oviductal environment. In vitro conditions maintaining differentiated growth of oviductal cells were determined by evaluating several media supplemented with different sera at various concentrations. Morphological features were used as indicators of physiological growth, and it became obvious that synthetic oviduct fluid (SOF) supplemented with either oestrous cow serum (OCS) or dextran-coated charcoal-treated fetal calf serum (DCC-FCS) helped to prevent dedifferentiation of bOECs (Expt 1). RT-real-time-PCR analysis revealed an increased mRNA content of the oviduct-specific glycoprotein GP 85-97 when using lower serum concentrations ( 2 and $5 \%$ compared with $10 \%$; Expt 2 ). In subsequent experiments in which cell-free cultured controls and cocultured embryos were compared, co-cultured embryos showed an increased rate of cleavage $(P<0.05)$ after 3 days. Successive cell-free culture until day 8 resulted in a lower rate of blastocyst development $(P<0.05)$ and reduced ATP content $(P<0.05)$ of co-cultured versus control embryos (Expt 3). Long-term co-culture (8 days) in SOF with $5 \%$ OCS increased the expression of developmentally relevant genes (glucose transporter 1 (Glut-1) and heat shock protein (HSP 70)) in co-cultured versus control embryos (Expt 4). Higher embryonic Glut-1 mRNA expression after co-culture was obvious when using $10 \%$ DCC-FCS, but was not significant when culture medium was supplemented with $10 \%$ rather than $5 \%$ OCS (Expt 5 ). In conclusion, SOF with 5\% OCS supports differentiated growth of bOECs. Co-culture under these conditions improves early cleavage rate, but not blastocyst development, and increases the expression of developmentally relevant genes influenced by type of serum and serum concentration.

\section{Introduction}

Early embryonic development takes place in the oviduct, where the preimplantation embryo experiences a changing environment during the reproductive cycle (Hunter, 1988; Leese, 1988; Ellington, 1991). A good in vitro model of this system is needed to broaden our understanding of the complex embryo-maternal interactions.

Historically, in vitro-cultured bovine embryos struggled to pass the so-called ' 8 - to 16-cell developmental block', a culture-induced event during the maternal-to-zygotic transition (Wright and Bondioli, 1981; Eyestone and First, 1991). In vitro culture systems resembling the reproductive tract environment were improved to support preimplanta-

*Present address: Department of Physiology, Technical University Munich-Weihenstephan, Weihenstephaner Berg 3, 85350 Freising, Germany

${ }^{\dagger}$ Correspondence

Email: k.prelle@gen.vetmed.uni-muenchen.de tion embryo development to pass this block. Synthetic oviduct fluid (SOF), a composition of ovine oviduct fluid (Tervit et al., 1972), and other simple media (Chatot et al., 1989; Lawitts and Biggers, 1991) were capable of supplying the embryonic requirements in vitro. Most of these media were supplemented with serum; however, the undefined nature and variability in serum composition directed research efforts to serum-reduced or completely serum-free 'defined' media (Thompson, 1996). Nevertheless, defined media in which proteins are replaced, for example, by polyvinyl alcohol (PVA), are less able to support embryo development and the resulting embryos are metabolically compromised (Pinyopummintr and Bavister, 1991; Krisher et al., 1999).

The general lack of understanding about the developmental block in vitro, as well as early developmental processes and metabolism of bovine embryos, led to the advent of co-culture systems using somatic cells of the reproductive tract, typically oviductal epithelial cells (OECs) (Gandolfi and Moore, 1987; Thibodeaux et al., 
1992). The beneficial effects on blastocyst development are thought to be due to embryotrophic factors provided by the epithelial cells (Gandolfi et al., 1989, 1992), and also to reduction of $\mathrm{O}_{2}$ tension (Fukui et al., 1991) and glucose concentration by these cells (Bavister, 1995).

Embryo co-culture has proven to be an inappropriate system for production of embryos for commercially focused purposes, but it is a suitable model for studying embryomaternal interactions. A deeper insight into this complex, including the signalling between both components, can be efficiently obtained by using an in vitro system that mimics the in vivo environment and most closely fulfils the requirements of both the cellular component and embryos that might be quite different. The most important prerequisite is to prevent the loss of physiological features (dedifferentiation) of the OECs, which mediate the maternal and cellular effects on embryonic development in vivo. This can be achieved in a number of ways including growing bovine OECs (bOECs) on permeable matrices such as cellulose nitrate (Reischl et al., 1999). Furthermore, medium and serum supplementation have to be empirically determined, and differences must be evaluated by cell morphology and by studying the expression of oviductspecific genes, such as glycoprotein GP 85-97 (Malayer et al., 1988; Sendai et al., 1994).

The effects of co-culture on embryo development are typically evaluated by rates of cleavage and development to the blastocyst stage, as well as by assessing metabolic activity and expression of genes that indicate developmental capacity. As ATP production is a key regulator of embryo development and reflects metabolic activity, ATP content can be used to characterize embryo viability (Thompson, 2000). Expression of the glucose transporter 1 (Glut-1) gene is frequently used to describe differences between different culture systems (Wrenzycki et al., 1998, 2001). Glut-1 mediates cellular glucose incorporation into embryonic cells and is necessary for transition from the morula to blastocyst stage (Leese, 1995). Glut-1 mRNA expression of in vivo-derived embryos was more than double that of in vitro-produced embryos (Niemann and Wrenzycki, 2000). The regulation of expression of genes related to 'stress' responses (Leese et al., 1998), such as heat shock protein (HSP) genes (Donati et al., 1990), is of particular interest because it is known to be affected by in vitro culture conditions and is different between in vivoand in vitro-derived embryos (Wrenzycki et al., 1999).

The aim of the present study was to establish a co-culture system for bovine in vitro-produced (IVP) embryos with bOECs as a model to study embryo-maternal communication. First, the effect of common cell culture media (tissue culture medium (TCM) 199 and Ham's F10) and embryo culture media (SOF and modified Parker's medium (MPM)) on differentiated bOEC growth was compared. Different parameters of cell morphology were investigated by electron microscopy and expression of GP 85-97 was quantified by RT-real-time-PCR to define culture conditions that support cells in a state most similar to that in vivo. Effects of short-term co-culture to mimic the 3 days of embryo migration through the oviduct in vivo (Gordon, 1994) were described by rate of embryonic development, ATP content and number of cells. Long-term co-culture for 8 days using different types and quantities of serum was evaluated by comparing blastocyst development and Glut-1 and HSP 70 mRNA expression.

\section{Materials and Methods}

\section{Isolation and culture of bovine oviduct epithelial cells (bOECS)}

Oviducts from cows at oestrus detected by a mature preovulatory follicle together with oestrous mucus were collected at a local abattoir, trimmed free of surrounding tissue and ligated at the infundibulum and at the isthmusuterus junction. The complete organ was rinsed with PBS containing $100 \mathrm{iu}$ penicillin $\mathrm{ml}^{-1}$ (Seromed, Berlin) and $100 \mu$ g streptomycin $\mathrm{ml}^{-1}$ (Seromed), disinfected with $70 \%$ $(\mathrm{v} / \mathrm{v})$ ethanol and transported in PBS plus antibiotics on ice to the laboratory within $1 \mathrm{~h}$.

The epithelial cells were isolated according to Witkowska (1979) by opening the oviduct longitudinally and scraping the mucosal epithelial layer with a sterile glass slide, and were further processed as described by Reischl et al. (1999). In brief, cells were collected in $2.5 \mathrm{ml}$ Hepes-buffered TCM 199 (ICN, Eschwege) $(\mathrm{TCM} / \mathrm{H})+10 \%$ fetal calf serum (FCS; Gibco BRL, Karlsruhe), and were pooled from three oviducts before being washed twice by centrifugation at $170 \mathrm{~g}$ for $5 \mathrm{~min}$ each. The cell pellet was incubated in $2 \mathrm{ml} 0.25 \%$ $(\mathrm{w} / \mathrm{v})$ trypsin- $0.02 \%(\mathrm{v} / \mathrm{v})$ EDTA solution (Sigma, Deisenhofen) for $8 \mathrm{~min}$ at $37^{\circ} \mathrm{C}$. Finally, the cells were washed in $\mathrm{TCM} / \mathrm{H}+10 \%$ FCS, centrifuged at $170 \mathrm{~g}$ for $5 \mathrm{~min}$ and counted before plating.

\section{In vitro production of bovine embryos}

Bovine embryos were produced using slight modifications to previously described methods (Stojkovic et al., 1995). In brief, cumulus-oocyte complexes (COCs) were collected from ovaries obtained from an abattoir by aspirating follicles $2-8 \mathrm{~mm}$ in diameter and washing them twice in preincubated $\left(39^{\circ} \mathrm{C}, 5 \% \mathrm{CO}_{2}\right.$ in air) TCM 199 buffered with $1 \mathrm{mmol}$ sodium bicarbonate $\mathrm{I}^{-1}$ (TCM/B) supplemented with $10 \%$ OCS. OCS was prepared by collecting blood from cows at standing oestrus that had been hormonally synchronized and verified by determination of progesterone concentration. After centrifugation at $4800 \mathrm{~g}$ for $25 \mathrm{~min}$, serum was pooled from three cows and heat-inactivated $\left(56^{\circ} \mathrm{C}\right.$, $25 \mathrm{~min}$ ) before aliquots were stored at $-20^{\circ} \mathrm{C}$. COCs with a dense cumulus layer and a dark, evenly granulated cytoplasm were selected and matured in vitro in $\mathrm{TCM} / \mathrm{B}$ supplemented with $10 \%$ OCS and 0.01 iu $\mathrm{ml}^{-1}$ of each of bFSH and bLH (Sioux Biochemicals, Sioux Center, IA) for $24 \mathrm{~h}$ at $39^{\circ} \mathrm{C}$ in $5 \% \mathrm{CO}_{2}$ in air. In vitro fertilization was performed for an additional $20 \mathrm{~h}$ in Tyrode's albuminlactate-pyruvate medium containing $6 \mathrm{mg}^{\mathrm{BSA}} \mathrm{ml}^{-1}$ 
(Sigma), $10 \mu \mathrm{g}$ heparin $\mathrm{ml}^{-1}$ (Sigma) and frozen-thawed semen $\left(10^{6}\right.$ spermatozoa $\left.\mathrm{ml}^{-1}\right)$ prepared by swim-up procedure (Parrish et al., 1986). Cumulus cells were removed from the presumptive zygotes (day 1) by vortexing (180 s). The embryos were washed twice in the same medium used in the subsequent culture experiment and groups of 30 embryos were either transferred on to the precultured bOECs on cellulose nitrate in one well of a fourwell plate (Nunc, Roskilde) in $600 \mu$ l of the specific culture medium (co-culture) or into the same medium without bOECs (control).

\section{Experiment 1: comparison of different media and serum sources with respect to bOEC morphology}

For a 2 day pre-culture at $37^{\circ} \mathrm{C}$ in a humidified atmosphere of $5 \% \mathrm{CO}_{2}$ in air, $0.8 \times 10^{6}$ cells were plated in $800 \mu \mathrm{l} \mathrm{TCM} / \mathrm{B}$ with $10 \%$ FCS per well of a four-well plate on round cellulose nitrate sheets $(13 \mathrm{~mm}$ in diameter, $0.45 \mu \mathrm{m}$ pore size; Sartorius, Göttingen). Four different media and three different sera ( $4 \times 3$ factorial experiment) were compared. The pre-cultured cells were subsequently cultured for 6 days in either TCM/B (Gibco BRL), MPM, SOF or Ham's F10 (Sigma) as basic media, and each was supplemented with either 10\% FCS, OCS or dextran-coated charcoal-treated fetal calf serum (DCC-FCS), and the medium was changed every $48 \mathrm{~h}$. DCC-FCS was prepared by mixing $400 \mathrm{ml}$ FCS two times with $900 \mathrm{ml} 0.01 \mathrm{~mol}$ Tris- $\mathrm{HCl}{ }^{-1}$ containing 0.25 g dextran (Pharmacia Biotech, Uppsala) and 2.25 g charcoal (Merck, Darmstadt). The solution was incubated two times for 45 min each at $45^{\circ} \mathrm{C}$ and centrifuged at $850 \mathrm{~g}$ for $20 \mathrm{~min}$ before filtration (Wobus et al., 2001).

Morphological evaluation of oviductal cells cultured in different media and sera. After 8 days of culture the epithelial cell surface (cilia, pores, microvilli and dome shape), as well as intercellular attachment, was evaluated by scanning electron microscopy. Transmission electron microscopy was used to examine intracellular organelles (mitochondria, rough endoplasmic reticulum (rER) with cisterna, Golgi apparatus), glycogen accumulation and intercellular junctions.

For scanning electron microscopy, the cellulose nitrate sheets with bOECs were washed in $\mathrm{PBS}(-)$ (without $\mathrm{Ca}^{2+}$ and $\mathrm{Mg}^{2+}$ ), fixed with $2.1 \%(\mathrm{w} / \mathrm{v})$ glutaraldehyde (Serva, Heidelberg) and dehydrated in a graded series of acetone before critical-point drying over $\mathrm{CO}_{2}$ (CDP 020; BAL-TEC, Walluf). After fixing the samples on an aluminium holder, they were coated with a $12 \mathrm{~nm}$ layer of gold-palladium in a sputter coater (SCD 040; BAL-TEC) and evaluated using a digital scanning microscope (DSM; Zeiss, Jena).

For transmission electron microscopy, bOECs were rinsed in PBS(-) and sodium cacodylate buffer, fixed in Karnovsky's solution (Karnovsky, 1965) and pre-contrasted with $1 \%(\mathrm{v} / \mathrm{v}$ ) osmium tetroxide (Plano, Wetzlar) and $1.5 \%$ $(\mathrm{w} / \mathrm{v})$ potassium ferrocyanide (Sigma). The cells were dehydrated in a graded series of ethanol and embedded in
Epon (Polysience, Warrington). Ultrathin sections (60 nm) with silver interference were placed on copper grids, stained with uranyl acetate and lead citrate (Plano), and examined under a transmission electron microscope (Zeiss 902). For each electron microscopy technique, two sheets were prepared per replicate and treatment. The media/sera comparison was repeated three times.

\section{Experiment 2: effect of serum concentrations on bOEC morphology and expression of GP 85-97 mRNA}

SOF and TCM/B were supplemented with 2, 5 or $10 \%$ FCS or OCS to study the effect of reduced serum content. bOECs were prepared and pre-cultured as in Expt 1 and cultured for an additional 6 days in the different media combinations with a change in medium every $48 \mathrm{~h}$. The serum reduction experiment was performed five times. Morphological evaluation of oviduct cells was done as in Expt 1.

RT-real-time-PCR analysis of $m R N A$ expression in bOECs. The mRNA expression of the oviduct-specific glycoprotein GP 85-97 was analysed by RT-real-time-PCR after 8 days of culture to determine the physiological status of the bOECs. Four cellulose nitrate sheets per treatment with the attached monolayer were transferred to a $1.5 \mathrm{ml}$ reaction tube and vortexed in $300 \mu$ l lysis buffer (Qiagen, Hilden). After removing the sheets, the lysate containing RNA was frozen at $-80^{\circ} \mathrm{C}$. Total RNA was extracted according to the manufacturer's protocol of the RNeasy total RNA extraction kit (Qiagen) and incubated with $10 \cup$ RNase-free DNase (Roche Diagnostics, Mannheim) for $25 \mathrm{~min}$ at $37^{\circ} \mathrm{C}$. RNA (40 ng) was reverse transcribed in $40 \mu$ l RT reaction mixture containing $0.01 \mathrm{~mol}$ dithiothreitol $\mathrm{I}^{-1}$ (Gibco BRL), $1.32 \mu \mathrm{g}$ random hexamer primers (Roche Diagnostics), $1 \mathrm{mmol}$ of each dNTP $\mathrm{I}^{-1}$ (MBI Fermentas, St Leon-Rot), $40 \cup$ Moloney murine leukaemia virus (M-MuLV) reverse transcriptase (Gibco BRL), $5 \times$ reaction buffer (Gibco BRL) and RNase-free water for $1 \mathrm{~h}$ at $40^{\circ} \mathrm{C}$. The reaction was terminated by heating at $95^{\circ} \mathrm{C}$ for $5 \mathrm{~min}$, and was cooled on ice and stored at $-20^{\circ} \mathrm{C}$ until use.

Quantification of mRNA was performed using an $\mathrm{ABI}$ PRISM $^{\circledR} 7700$ Sequence Detection System (PE Applied Biosystems, Weiterstadt) and SYBR ${ }^{\circledR}$ Green (PE Applied Biosystems) as a double-strand DNA-specific fluorescent dye. Nine RNA dilutions (1:2) from $10 \mathrm{ng} \mu \mathrm{l}^{-1}$ to $0.039 \mathrm{ng}$ $\mu l^{-1}$ were used to produce a standard curve to calculate the GP 85-97 expression in bOECs. The dilutions were supplemented with carrier synthetic A-oligonucleotides (Pharmacia Biotech) to a final concentration of $10 \mathrm{ng} \mu \mathrm{I}^{-1} \mathrm{RNA}$ solution and were reverse transcribed together with the bOEC RNA samples. Aliquots of the standards were primed separately for GP 85-97 (gene of interest) and GAPDH to calculate the corresponding amplification efficiencies by the ABI PRISM ${ }^{\circledR}$ software. GAPDH was used as a housekeeping gene for normalization. Regulation of this gene due to different media and various serum concentrations was evaluated in 
Table 1. Expression of GAPDH mRNA in bovine oviduct epithelial cells (bOECs) cultured in different media, types of serum and serum concentrations (Expt 2)

\begin{tabular}{lcccc}
\hline Culture & SOF plus OCS & SOF plus FCS & TCM plus OCS & TCM plus FCS \\
\hline 2\% Serum & $4.46 \pm 0.56$ & $4.6 \pm 0.78$ & $6.23 \pm 0.86$ & $9.35 \pm 1.9$ \\
5\% Serum & $4.25 \pm 0.48$ & $8.37 \pm 1.77$ & $8.4 \pm 2.2$ & $9.86 \pm 1.94$ \\
$10 \%$ Serum & $9.25 \pm 2.77$ & $7.96 \pm 2.05$ & $7.84 \pm 1.1$ & $10.98 \pm 1.98$ \\
\hline
\end{tabular}

SOF: synthetic oviduct fluid; FCS: fetal calf serum; TCM: tissue culture medium; OCS: oestrous cow serum.

Data are presented in RNA units (mean \pm SEM).

advance by RT-PCR analysis. Although differences in GAPDH mRNA abundance were found between the experimental groups, these differences were not significant (Table 1). Furthermore, the differences in expression of the gene of interest (GP 85-97) were much greater than those of GAPDH, thereby justifying its use for normalization.

Amplification mixes $(25 \mu \mathrm{l})$ contained $2 \mu \mathrm{l}$ bOEC cDNA solution, $2 \times \mathrm{SYBR}^{\circledR}$ Green Master Mix, $0.25 \mathrm{U}$ AmpErase uracil N-glycosylase (PE Applied Biosystems) and $0.3 \mu \mathrm{mol}$ $\mathrm{I}^{-1}$ of forward and reverse primers for GAPDH, or $0.4 \mu \mathrm{mol}$ $\mathrm{I}^{-1}$ of forward and $0.2 \mu \mathrm{mol} \mathrm{l}^{-1}$ of reverse primer for GP 85-97, respectively. Amplification primers (bovine GP 85-97, accession no. D16639: forward primer: 5'-TGTCCACGTTTTCCAACCG-3 (324-342); reverse primer: 5'-GGAGGGCGATCACTGAACTG-3' (374-355); bovine GAPDH, accession no. U85042: forward primer: 5'-ACCACTTTGGCATCGTGGAG-3' (461-480); reverse primer: 5'-GGGCCATCCACAGTCTTCTG-3' (536-517)) were designed using Primer Express ${ }^{\circledR}$ software (PE Applied Biosystems). PCR started with activation of AmpErase for 2 min at $50^{\circ} \mathrm{C}$, followed by $10 \mathrm{~min}$ denaturation at $95^{\circ} \mathrm{C}$ and 40 cycles of denaturation $\left(95^{\circ} \mathrm{C}, 15 \mathrm{~s}\right)$ and annealing/extension $\left(60^{\circ} \mathrm{C}\right.$, $1 \mathrm{~min}$ ). The identity of the amplified GP 85-97 cDNA was confirmed by purification and restriction enzyme digestion (Msel; MBI Fermentas; 17 and 34 bp), and the specificity of the GAPDH PCR product was determined by sequencing.

Relative mRNA expression of GP 85-97 in the bOEC samples was calculated using ABI PRISM ${ }^{\circledR} 7700$ software according to the $C_{T}$ (threshold) of the samples. $C_{T}$ is defined as the cycle number at which the fluorescence intensity determined after each PCR cycle exceeds a fixed base line and represents RNA arbitrary units (RAU) relative to the specific standard curve. The mRNA expression of GP 85-97 was calculated after normalization to GAPDH by dividing the corresponding RAU in each sample (RAU GP 8597/RAU GAPDH). The RT-real-time-PCR was performed using bOECs from three repeated culture experiments and real-time-PCR analysis was repeated twice per cDNA sample.

\section{Experiment 3: short-term co-culture of bovine IVP embryos with bOECS}

For the co-culture experiment, $4 \times 10^{6}$ cells per $5 \mathrm{ml}$ were pre-cultured on six cellulose nitrate sheets in a $6 \mathrm{~cm}$ Petri dish for 2 days in TCM/B with 10\% FCS. The denuded day 1 zygotes were cultured with this bOEC monolayer on cellulose nitrate (co-culture) or without (control) both in SOF (supplemented with $2 \%(\mathrm{v} / \mathrm{v})$ essential amino acids stock (Gibco BRL), 1\% (v/v) non-essential amino acids stock (Gibco BRL), $0.025 \%(\mathrm{w} / \mathrm{v})$ gentamycin (Sigma)) and in 5\% OCS in a humidified atmosphere of $39^{\circ} \mathrm{C}, 5 \% \mathrm{CO}_{2}, 5 \% \mathrm{O}_{2}$ and $90 \% \mathrm{~N}_{2}$. This experiment was repeated seven times.

Evaluation of rates of development. After short-term $(48 \mathrm{~h})$ co-culture, the developmental potential of both embryo groups was evaluated at day 3 of development on the basis of the cleavage rate (number of cleaved embryos out of selected oocytes). Afterwards, both groups were transferred separately to a cell-free culture system of SOF containing the same ingredients but $10 \%$ OCS, and the rate of blastocyst development (number of blastocysts out of selected oocytes) was determined at day 8 .

Determination of ATP content and total number of cells of day 8 blastocysts. The ATP content of short-term cocultured and control embryos was measured at day 8 using a commercial assay based on the luciferin-luciferase reaction (bioluminescent somatic cell assay kit; Sigma) (Stojkovic et al., 1999). In brief, after washing the embryos three times in ATP sample buffer, each embryo was transferred individually into a polypropylene tube (Sarstedt, Nürmbrecht) containing $50 \mu \mathrm{l}$ ATP buffer on ice/water. After addition of $100 \mu \mathrm{l}$ ice-cold somatic cell-releasing buffer, the reaction mix was incubated for $5 \mathrm{~min}$ on ice/water. One hundred microlitres of the ice-cold luciferin-luciferase assay mix prepared by adding $960 \mu \mathrm{l}$ ATP dilution buffer to $40 \mu$ l luciferin-luciferase stock solution was added to each embryo and incubated for $5 \mathrm{~min}$ at room temperature in darkness. The resulting light emission was measured by a luminometer (Bioluminat Junior; Berthold, Wildbad) and the ATP content was determined by linear regression of a seven-point standard curve (0-6 pmol per tube).

After ATP determination, the embryos were washed in PBS and the zona pellucida of non-hatched embryos was removed by pronase digestion $(0.5 \%(\mathrm{w} / \mathrm{v})$ in PBS for $2 \mathrm{~min}$ ). Subsequently, the embryos were transferred to $50 \mu \mathrm{l}$ 4'-6'-diamino-2-phenyl-indole (DAPI) (Sigma; $10 \mu \mathrm{g} \mathrm{ml}^{-1}$ ) for staining of cell nuclei and were incubated for $1 \mathrm{~min}$ at $37^{\circ} \mathrm{C}$ in darkness. Each individual embryo was transferred in a small amount of PBS on to a glass slide and the number of cells was counted using an epifluorescence microscope (Axiovert 135; Zeiss) at $\times 400$ magnification under UV light (365 nm excitation). 
Experiment 4: long-term co-culture of IVP embryos in SOF with $5 \%$ OCS

Long-term co-culture was performed for 8 days on bOECs prepared as described above (Expt 3). The culture medium SOF was supplemented with $5 \%$ OCS and half of the medium $(300 \mu \mathrm{l})$ was changed every $48 \mathrm{~h}$ to avoid the negative effects of, for example, ammonia, generated from the spontaneous degradation of amino acids during culture and amino acid metabolism, and other toxic metabolites (Gardner et al., 1994). The control embryos were also cultured in SOF plus $5 \%$ OCS but without bOECs. This experiment was repeated five times. Rate of blastocyst development was determined on day 8 before RNA extraction.

$R T$-real-time-PCR analysis of expression of Glut-1 and HSP 70 mRNA in long-term co-cultured embryos. Embryos were washed three times in PBS supplemented with $0.1 \%$ $(\mathrm{w} / \mathrm{v})$ polyvinyl pyrrolidone (Sigma) and stored in pools of four embryos of the same developmental stage at $-80^{\circ} \mathrm{C}$ in a minimum volume until processed for RT-real-time-PCR. Total embryonic RNA of four embryos was isolated as described by Prelle et al. (2001). In brief, $100 \mu$ l extraction buffer $\left(0.2 \mathrm{~mol} \mathrm{NaCl} \mathrm{I}^{-1}, 0.025 \mathrm{~mol}_{\text {Tris }} \mathrm{I}^{-1}(\mathrm{pH} 7.2), 1 \mathrm{mmol}\right.$ EDTA ${ }^{-1}$ ) and 4 ng synthetic A-oligonucleotides (Pharmacia Biotech) as a carrier were added to the thawed embryos, and RNA was extracted with $75 \mu$ l chloroform:isoamyl alcohol $(24: 1)$ and $75 \mu \mathrm{l}$ phenol. After centrifugation at $16000 \mathrm{~g}$ for $10 \mathrm{~min}$, the aqueous phase was mixed with $100 \mu \mathrm{l}$ chloroform: isoamyl alcohol and after another centrifugation at $16000 \mathrm{~g}$ for $10 \mathrm{~min}, 2 \mu \mathrm{l}$ of the coprecipitant seeDNA ${ }^{\circledR}$ (Amersham Pharmacia, Amsterdam) and $0.1 \times$ volume of the aqueous phase of 3 mol sodium acetate $\mathrm{I}^{-1}$ were added. The RNA pellet was washed in ethanol and dissolved in $20 \mu \mathrm{l}$ RNase-free water. For the RT reaction, $10 \mu \mathrm{l}$ total embryonic RNA (equivalent to 2 blastocyst RNA units (BRUs)) was mixed with $10 \mu \mathrm{l}$ RT master mix containing $0.66 \mu \mathrm{g}$ random hexamer primer (Roche Diagnostics), $1 \mathrm{mmol}$ of each dNTP $\mathrm{I}^{-1}$ (MBI Fermentas), 0.01 mol dithiothreitol I-1, 20 U M-MuLV-RT and $5 \times$ RT buffer (all Gibco BRL).

Real-time PCR reaction mix $(25 \mu \mathrm{l})$ contained $1.75 \mu \mathrm{l}$ embryonic cDNA (equivalent to $0.175 \mathrm{BRU}), 2 \times$ $\mathrm{SYBR}^{\circledR}$ Green master mix, $0.25 \cup$ AmpErase and $0.3 \mu \mathrm{mol}$ $\mathrm{I}^{-1}$ of each specific forward and reverse primer (bovine Glut-1, accession no. M60448: forward primer: 5'-AACCTGCTGGCCTTCGTGT-3' (468-486); reverse primer: 5'-AGCGACCCAGGATCAGCAT-3' (549-531); bovine HSP 70, accession no. X53827: forward primer: 5'-CCCCAAGCTATGTCGCCTT-3' (147-165); reverse primer: 5'GGATTCATTGCGACTTGGTTC-3' (222-202)). GAPDH was proven to be a non-regulated housekeeping gene in advance $\left(\mathrm{C}_{\mathrm{T}} \mathrm{GAPDH}\right.$ co-culture: $28.78 \pm 0.36 ; \mathrm{C}_{\mathrm{T}} \mathrm{GAPDH}$ control: $28.23 \pm 0.38$ ). Four dilutions of embryonic cDNA $(0.3,0.15,0.075$ and $0.037 \mathrm{BRU})$ were primed separately for each gene of interest to create standards for calculating amplification efficiency during real-time-PCR. PCR conditions were the same as for GP 85-97, and amplification and quantification were performed following the standard curve method described previously (Kölle et al., 2001; Prelle et al., 2001). The expression (in arbitrary units (AU)) obtained for co-cultured embryos was calibrated by the corresponding values obtained for cell-free cultured control embryos, which were set to 1 . Specificity of the amplification products was confirmed by sequencing.

\section{Experiment 5: long-term co-culture of IVP embryos in SOF with $10 \%$ DCC-FCS versus $10 \%$ OCS}

The influence of different types of serum on differentiation of bOECs with respect to their embryotrophic potential on embryos was investigated in a 8 day co-culture using SOF with 10\% OCS and 10\% DCC-FCS, respectively. The control embryos for each group were cultured in the same medium without bOECs and half of the medium was changed every second day in each system. The experiment was repeated three times. Rate of development was determined at day 8 and mRNA expression of blastocysts was investigated as described for Expt $4\left(\mathrm{C}_{\mathrm{T}} \mathrm{GAPDH}\right.$ with $10 \%$ OCS: $27.68 \pm 0.55$ (co-culture) versus $27.38 \pm 0.92$ (control); $C_{\mathrm{T}}$ GAPDH with $10 \%$ DCC-FCS: $30.97 \pm 0.41$ (co-culture) versus $29.53 \pm 0.39$ (control)).

\section{Statistical analyses}

Data for GP 85-97 mRNA expression of bOECs (Expt 2) were analysed using Kruskal-Wallis $\mathrm{h}$ test to evaluate the influence of basic medium (TCM and SOF) and type of serum (OCS and FCS). Subsequently, differences between various serum concentrations (2, 5 and $10 \%)$ were analysed by Mann-Whitney $U$ test.

Rate of cleavage and ATP content after short-term coculture (Expt 3) were analysed using one-way ANOVA, and ATP content and number of cells at different developmental stages were analysed by Mann-Whitney $U$ test. The correlation between ATP content and number of cells was evaluated by calculating the Spearman-rho coefficient.

Rates of development in the long-term co-culture experiment using 5\% OCS (Expt 4) were analysed by ANOVA. Data for embryonic mRNA expression were analysed using Student's one-sample $t$ test for logarithmic factors of calibrated expression values of co-cultured embryos compared with 1 (value of corresponding control embryos).

In the final co-culture experiment (Expt 5), the influence of type of serum (OCS or DCC-FCS) on embryonic development in the two culture systems was evaluated by chisquared analysis.

\section{Results}

Experiment 1: effect of different media and serum sources on bOEC morphology

Evaluation by electron microscopy revealed a polygonal, dome-shaped morphology of bOECs when cultured in TCM 199 or SOF similar to that observed in vivo. Regardless of the serum source, several pore-like membrane lesions $(<1 \mu \mathrm{m})$ were visible at the apical cell surface (Fig. 1a). In 

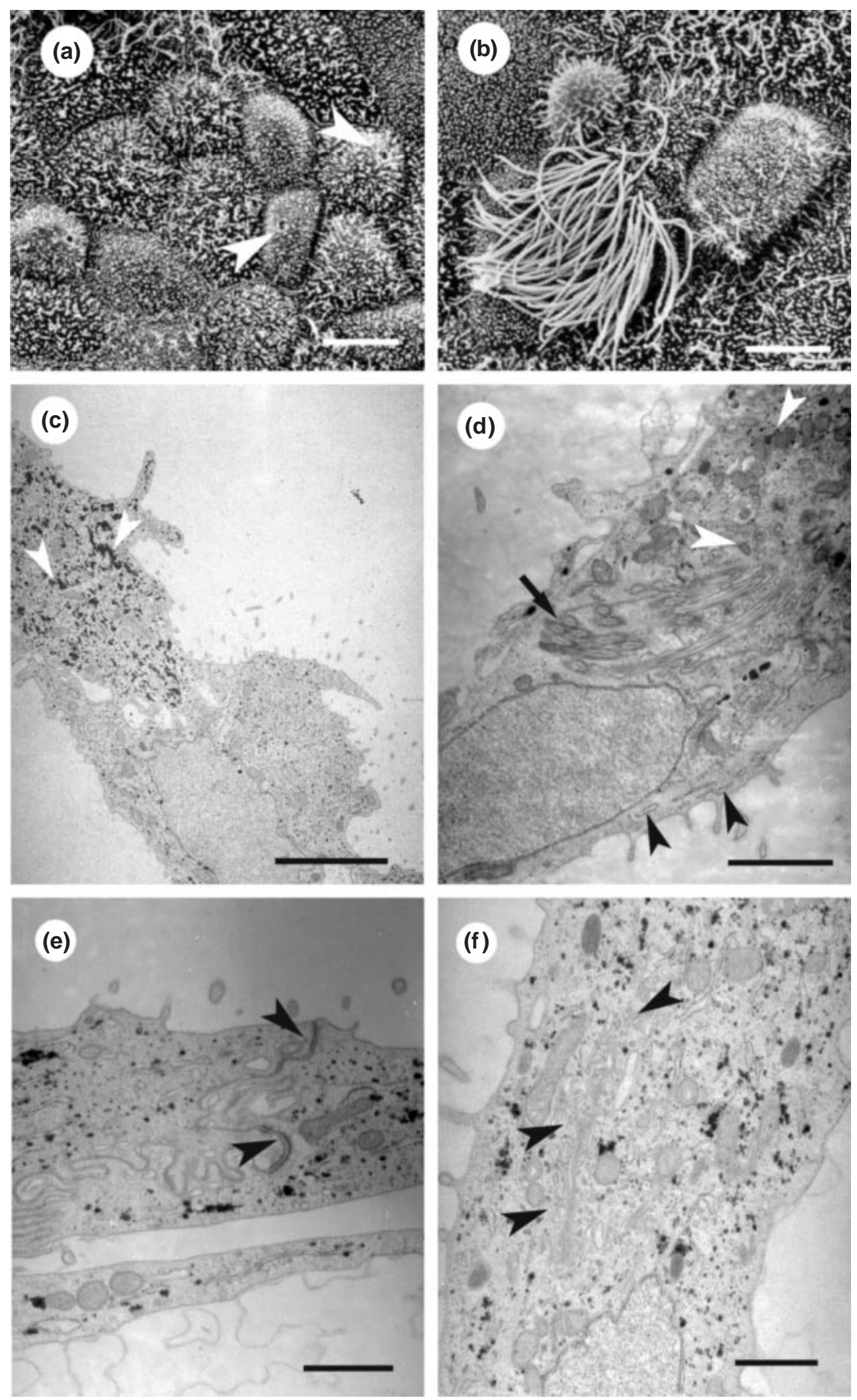

Fig. 1. (a,b) Scanning electron microscope images of bovine oviduct epithelial cell (bOEC) monolayers after $2+6$ days culture on cellulose nitrate (Expt 1). (a) Polygonal dome-shaped bOECs cultured in tissue culture medium (TCM) 199 with 10\% fetal calf serum (FCS) showing pore-like 


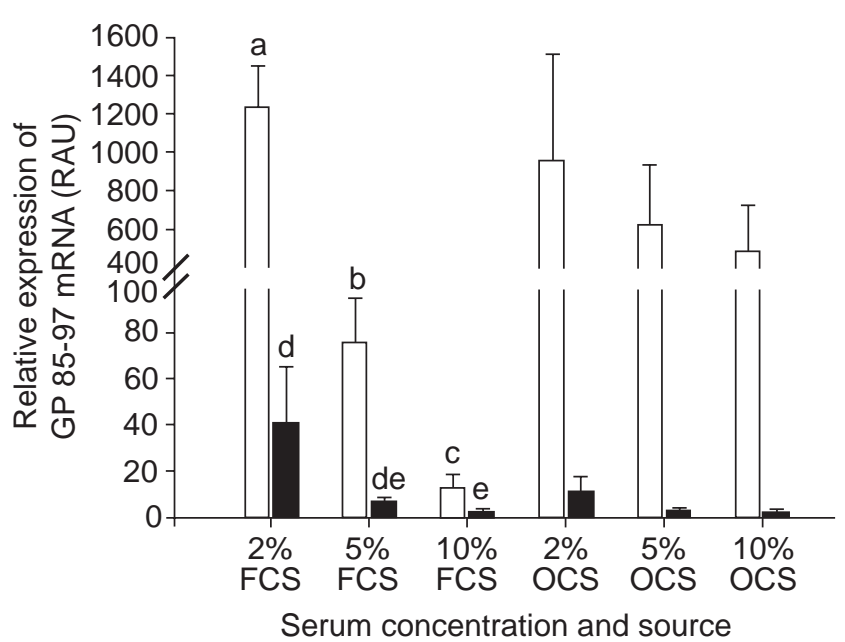

Fig. 2. Relative differences in abundance of GP 85-97 mRNA (in RNA arbitrary units, RAU) of bovine oviduct epithelial cells (bOECs) cultured in different combinations of basic media (tissue culture medium (TCM; $\mathbf{\square})$, synthetic oviduct fluid (SOF; $\square)$ ), serum sources (fetal calf serum (FCS), oestrous cow serum (OCS)) and concentrations (2, 5 and 10\%) after normalization for GAPDH expression (Expt 2). Values are mean \pm SEM. Significant differences are marked by different superscripts within basic media (a-c and de, $P<0.05$, Mann-Whitney $U$ test). Significant differences between media $(P<0.001)$ are not shown.

contrast, bOECs cultured in MPM or Ham's F10 were flat and spindle-shaped. Tight intercellular adhesion characterized by desmosomes, the typical in vivo epithelial cell connections, was observed only in cells cultured in SOF with OCS (Fig. 1e). This combination also showed an increased proportion of intracellular organelles in bOECs including a widespread Golgi apparatus, high number of mitochondria and numerous dilated rER (Fig. 1f). Culture in enriched media (TCM 199 and MPM) induced accumulation of glycogen in some cells (Fig. 1c). Regardless of culture medium, DCC-FCS increased the proportion of ciliated cells (Fig. 1b), which are characteristic of OECs in vivo, compared with other serum sources.

\section{Experiment 2: effect of serum concentrations on bOEC morphology and expression of GP 85-97 mRNA}

Independent of basic media, bOECs cultured in the presence of OCS showed epithelial-like cell morphology, whereas in the presence of FCS, cells were more flat and loosely connected with fewer cilia. In TCM 199 the effects of different serum concentrations or sources on cell morphology were less distinct compared with SOF, in which cells cultured in low serum concentrations contained a higher proportion of cell organelles, especially numerous mitochondria, Golgi apparatus, dilated rER and small vacuoles with secretory granules. Lower OCS concentrations also induced an increased proportion of cells carrying cilia with typical ' $9+2$ ' microtubule arrangement (Fig. 1d).

Significant differences in expression of GP 85-97 mRNA were detected between the cells cultured in different FCS concentrations $(P<0.05)$. Independent of basic media, the abundance of GP 85-97 mRNA increased with decreasing serum content. When OCS was used, the GP 85-97 mRNA expression of bOECs was similar to that of bOECs cultured with FCS in both basic media (Fig. 2). Culture in SOF significantly increased expression of GP 85-97 mRNA compared with culture in TCM, regardless of serum source and concentration $(P<0.001)$.

\section{Experiment 3: rates of development, ATP content and number of cells of bovine IVP embryos after short-term co-culture}

Short-term co-culture with bOECs significantly $(P<0.05)$ increased the cleavage rate of embryos on day 3 compared with the cell-free control (Table 2). However, the proportion of blastocyst development by day 8 was significantly reduced $(P<0.05)$.

The ATP content of individual expanded and hatching blastocysts at day 8 was significantly lower in the co-culture group compared with the control group $(P<0.05)$ (Fig. 3a). The number of cells of these embryos was determined by DAPI staining (Fig. 3b), and no differences were found between controls and co-cultured embryos (Table 3). As a consequence, the ATP content per cell was lower in cocultured embryos compared with controls (blastocysts: $6.29 \pm 0.64$ versus $6.98 \pm 0.68 \mathrm{fmol}$ per cell; expanded blastocysts: $6.37 \pm 0.62$ versus $7.07 \pm 0.62 \mathrm{fmol}$ per cell; hatching blastocysts: $6.65 \pm 1.12$ versus $6.69 \pm 1.21 \mathrm{fmol}$ per cell; hatched blastocysts: $6.96 \pm 1.84$ versus $7.26 \pm$ $1.05 \mathrm{fmol}$ per cell). A positive correlation was detected between number of cells and ATP content for both cocultured $(r=0.54)$ and control ( $r=0.65)$ embryos (Fig. 3c).

\section{Experiment 4: effect of long-term co-culture on embryonic development and $m R N A$ expression}

After long-term co-culture in SOF with 5\% OCS, there was no significant difference in rates of development between the co-cultured and control embryos at day 8

membrane lesions $(<1 \mu \mathrm{m})$ (arrowheads). (b) Cell grown in synthetic oviduct fluid (SOF) with 10\% dextran-coated charcoal-treated (DCC)FCS showing cilia. (c-f) Transmission electron microscope images of bOECs after $2+6$ days cultured on cellulose nitrate. (c) Intracytoplasmic glycogen accumulation (white arrowheads) in one cell close by another without glycogen after culture in TCM with $10 \%$ FCS. (d) Cells cultured in SOF with 5\% OCS displaying cilia with typical ' $9+2$ ' microtubule arrangement (arrow), numerous organelles (white arrowheads) and rough endoplasmic reticulum with visible cisternae (black arrowheads). (e) Cells in SOF with $10 \%$ OCS with tight intercellular connections (arrowheads) like desmosomes (centre), and tight junctions (apical). (f) Cells cultured in SOF with 10\% OCS displaying numerous organelles including mitochondria and distinct Golgi apparatus (arrowheads). Scale bars represent (a) $10 \mu \mathrm{m},(\mathrm{b}, \mathrm{c})$ $5 \mu \mathrm{m},(\mathrm{d}) 2 \mu \mathrm{m}$ and $(\mathrm{e}, \mathrm{f}) 1 \mu \mathrm{m}$. 
Table 2. Rates of development of bovine in vitro-produced (IVP) embryos after short-term co-culture (Expt 3)

\begin{tabular}{|c|c|c|c|c|c|c|}
\hline Culture system & $\begin{array}{c}\text { Number of } \\
\text { oocytes }\end{array}$ & $\begin{array}{c}\text { Cleavage rate } \\
\text { (day } 3)\end{array}$ & $\begin{array}{l}\text { Blastocysts } \\
\quad(\text { day 8) }\end{array}$ & $\begin{array}{l}\text { Expanded } \\
\text { blastocysts }\end{array}$ & $\begin{array}{c}\text { Hatched } \\
\text { blastocysts }\end{array}$ & $\begin{array}{c}\text { Total blastocyst } \\
\text { rate (day 8) }\end{array}$ \\
\hline Co-culture (with bOECs) & 872 & $81.2 \pm 1.8^{\mathrm{a}}$ & $8.8 \pm 1.2$ & $4.6 \pm 0.9$ & $2.6 \pm 0.3^{a}$ & $16.1 \pm 1.1^{\mathrm{a}}$ \\
\hline Control (without bOECs) & 794 & $74.3 \pm 2.2^{b}$ & $12.6 \pm 2.6$ & $7.4 \pm 1.1$ & $4.9^{b} \pm 0.9^{b}$ & $25.0 \pm 3.6^{b}$ \\
\hline
\end{tabular}

bOECs: bovine oviduct epithelial cells.

Data are presented as mean \pm SEM of percentage of oocytes selected for IVF.

abValues with different superscripts within columns differ significantly $(P<0.05$, ANOVA).

(Table 4). The content of Glut-1 mRNA tended to be higher in co-cultured embryos compared with controls, although this difference was not significant $(P<0.08$; Fig. $4 a)$. The content of HSP 70 mRNA was significantly higher $(P<0.05)$ in co-cultured expanded blastocysts than in the corresponding controls (Fig. 4b).

\section{Experiment 5: influence of different serum sources on co- cultured embryos}

Co-culture using each of 10\% OCS and 10\% DCC-FCS resulted in a lower rate of blastocyst development when compared with the cell-free control system $(P<0.05$ in DCC-FCS; $P<0.01$ in OCS). The proportion of hatched blastocysts in DCC-FCS was reduced markedly in the coculture system as well as in the control system compared with $10 \%$ OCS $(P<0.001)$. The total rate of blastocyst development was significantly lower in DCC-FCS independent of the culture system $(P<0.05)$ (Table 5).

Relative Glut-1 mRNA content was higher in co-cultured blastocysts in SOF supplemented with 10\% DCC-FCS (Fig. $5 a)$, although this increase was not significant $(P<0.08)$, whereas $10 \%$ OCS did not show an obvious effect on the expression of both HSP 70 and Glut-1 in co-cultured embryos (Fig. 5b).

\section{Discussion}

In the present study the effects of bOEC co-culture on bovine IVP embryo development were evaluated to assess its suitability as a model for studying embryo-maternal communication. Initially, four different media were compared using porous cellulose nitrate matrices that prevent dedifferentiation of bOECs (Reischl et al., 1999). These media, which were designed for somatic cell culture (TCM 199 and Ham's F10) and embryo culture media (SOF and MPM), were combined with three sera (FCS, DCC-FCS and OCS), and their effects on bOEC morphology and function in vitro were compared. SOF supplemented with OCS maintained polygonal morphology, typical of epithelial cells, as well as the functional status of bOECs most effectively, although this medium was initially designed and optimized for embryo culture (Tervit et al., 1972; Fukui et al., 1991). The DCC-FCS also efficiently supported the differentiated growth of bOECs, characterized by a high proportion of ciliated cells even after prolonged culture. Treating FCS with dextran-coated charcoal removes various molecules, including oestradiol (reduction of $97 \%$ from $75 \mathrm{pg} \mathrm{ml}^{-1}$ to $2.2 \mathrm{pg} \mathrm{ml}^{-1}$ ) (Fortunati et al., 1999), endogenous retinoids and growth factors (Wobus et al., 2001) such as fibroblast growth factor (FGF) and epidermal growth factor (EGF). A reduced content of mitogenic substances is likely to prevent dedifferentiation by not inducing cell proliferation, which is usually antagonistic to cell differentiation (Buchner and Wartenberg, 1997).

A lower concentration of serum in culture medium also reduces the growth factor content; however, some beneficial effects are maintained, including binding of toxic metals, support of cell attachment and provision of protease inhibitors (Barnes and Sato, 1980). In the presence of OCS, cells retained the epithelial-like morphology and secretory activity of embryotrophic substances characterized by small contrasted vacuoles and pore-like apical membrane lesions independent of the serum concentration. In addition, the occurrence of large Golgi apparatus typical of in vivo cells and numerous mitochondria in bOECs cultured in SOF with OCS was indicative of high metabolic activity, especially high synthesis of proteins stored in dilated rER (Geneser, 1986; Joshi, 1995), without obvious differences between $2 \%$ and $5 \%$ OCS. This finding might be due to a positive effect of oestrogen contained in OCS, as Nayak and Ellington (1977) demonstrated an influence of balanced oestrous hormones on the morphological and functional status of bOECs.

Lower serum concentrations affected the expression of oviduct-specific GP 85-97 mRNA in bOECs, which is secreted in vivo at the time of ovulation stimulated by oestrogen (Gerena and Kilian, 1990; Wegener and Kilian, 1992; Staros and Kilian, 1998). Significantly higher gene expression, probably due to differentiated growth as a consequence of reduced mitotic activity, was shown when using $2 \%$ or $5 \%$ instead of $10 \%$ FCS. GP $85-97$ expression has been used as a marker of bOEC functionality in a previous study (Reischl et al., 1999), in which ex vivoderived bOECs showed high expression, whereas in cultured cells the expression was reduced depending on time in vitro and culture system. In the present study, GP 85-97 mRNA abundance was not significantly influenced by the OCS concentration but expression was high when OCS was used instead of FCS, possibly due to a higher 


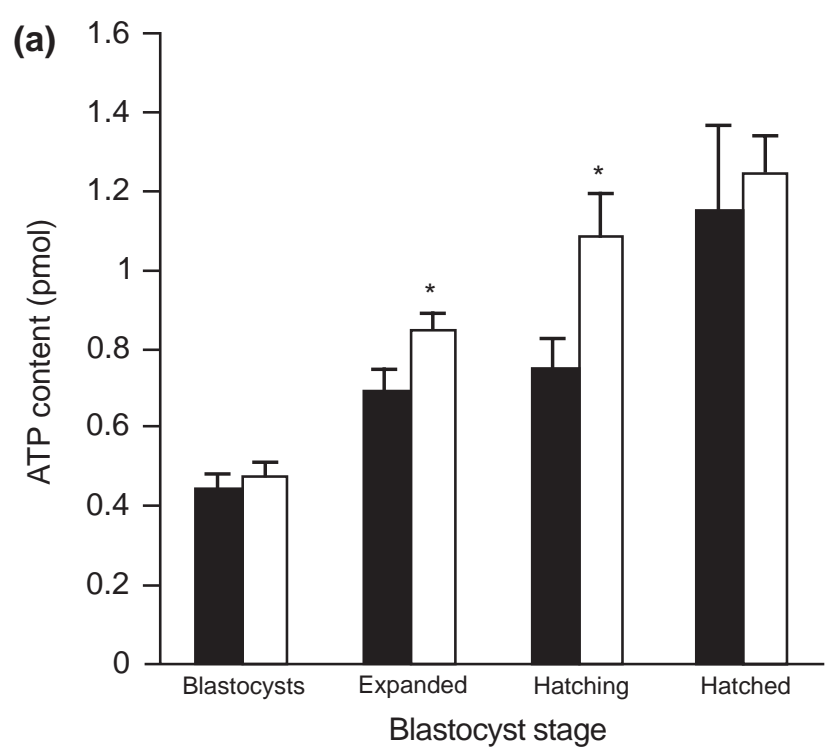

(b)

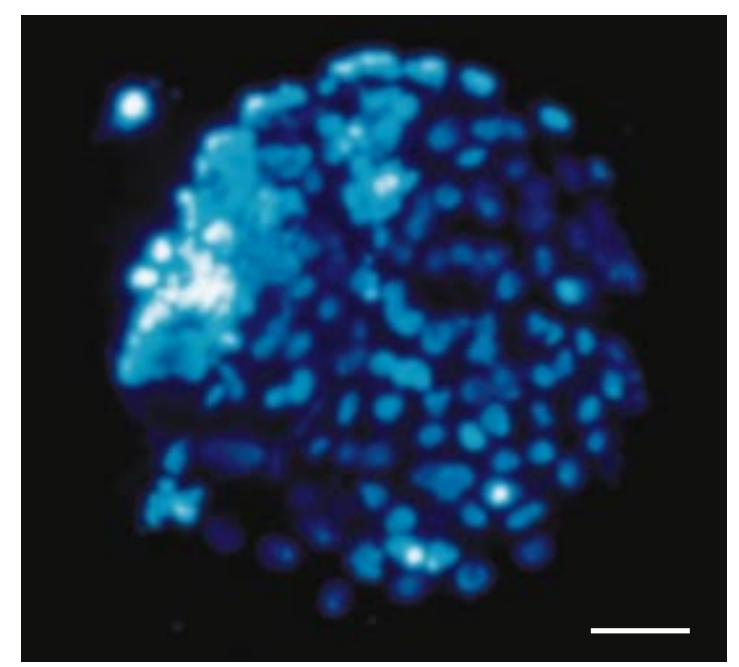

(c)

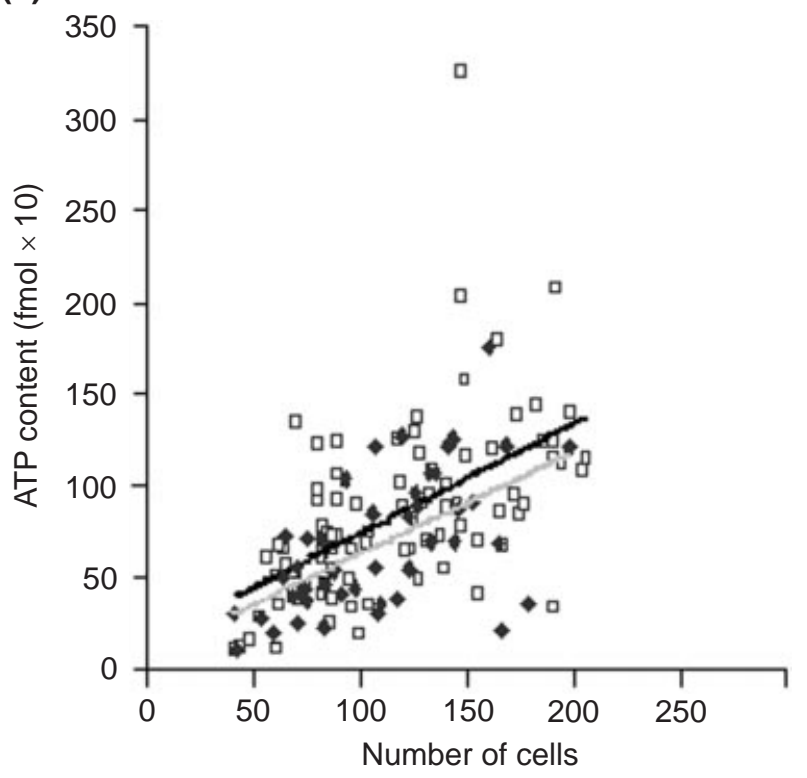

oestrogen content in OCS. Therefore, OCS or low FCS concentrations in a co-culture system could support differentiated cell growth and subsequent embryonic development by cellular secretion of embryotrophic factors. A low content of serum might also be beneficial because secreted factors will not be masked by serum proteins.

In the present study, SOF, which is known for its beneficial effect on embryo development, was shown for the first time to support differentiated bOEC growth. This was the initial step to establish a novel co-culture system as a model to study interactions between oviductal cells and bovine preimplantation embryos. Short-term co-culture in SOF with $5 \%$ OCS simulated the oviduct passage in vivo and increased the cleavage rate of co-cultured embryos on day $3(81.2 \%$ versus $74.3 \%)$, confirming results in sheep (Gandolfi and Moor, 1987) and cattle (Eyestone and First, 1989). This effect might be due in part to reduction of serum-derived glucose by differentiated bOECs (Bavister, 1995). Glucose has a negative effect on early embryonic development (Edwards et al., 1997) but can be metabolized into lactate and pyruvate by co-cultured cells (Cox and Leese, 1997). As early embryonic stages can use these two substances as energy sources (Leese et al., 1993), co-culture might have a beneficial effect on early cleavage rate.

However, the lower rate of blastocyst development in the short-term co-culture group on day 8 might be due to the harsh transfer on day 3 into the standard cell-free system during a sensitive phase of development (8- to 16-cell block) (Gordon, 1994). Alternatively, feeder cells could be removed and embryos could be cultured in conditioned medium, as an increased understanding of the changing requirements of early embryo development and the temporal relationship to the reproductive tract has led to the concept of 'sequential' culture by altering media components and physical conditions during the in vitro period (Thompson, 2000). Therefore, transfer into the cell-free culture system at day 3 might also act to select a small number of the most viable embryos that develop to blastocysts just because of these changing culture conditions. This presumptive higher viability should be proven by their tolerance to cryopreservation or by transferring co-cultured and control embryos to recipients and following their development to offspring.

Van Blerkom et al. (1995) demonstrated that for human

Fig. 3. Evaluation of ATP content and number of cells in bovine in vitro-produced (IVP) embryos (Expt 3). (a) ATP content (pmol) of various blastocyst stages of bovine IVP embryos generated in different culture systems. $\mathbf{\square}$ : Co-culture; $\square$ : control. Values are mean \pm SEM. Asterisks indicate significant differences between co-cultured and control embryos (ANOVA, $P<0.05$ ). (b) Hatched blastocyst, stained by $4^{\prime}-6^{\prime}$-diamidino-2-phenylindole (DAPI). Scale bar represents $20 \mu \mathrm{m}$. (c) Positive correlation between number of cells and ATP content $(\mathrm{fmol} \times 10)$ in both culture systems; grey regression curve and black diamonds $(\bullet)$ : co-culture group, $r=0.542, y=0.5545 x+7.1472$; black regression curve and open squares $(\square)$ : control group, $r=0.646, y=0.5953 x+$ 14.343 (Spearman-rho). 
Table 3. Effect of short-term co-culture on number of cells of day 8 in vitro-produced (IVP) bovine embryos (Expt 3)

\begin{tabular}{lcccc}
\hline Culture system & $\begin{array}{c}\text { Blastocysts } \\
\text { (day 8) }\end{array}$ & $\begin{array}{c}\text { Expanded } \\
\text { blastocysts }\end{array}$ & $\begin{array}{c}\text { Hatching } \\
\text { blastocysts }\end{array}$ & $\begin{array}{c}\text { Hatched } \\
\text { blastocysts }\end{array}$ \\
\hline $\begin{array}{c}\text { Co-culture } \\
\text { (with bOECs) }\end{array}$ & $\begin{array}{c}79.6 \pm 5.9 \\
(n=16)\end{array}$ & $\begin{array}{c}119.7 \pm 7.0 \\
(n=19)\end{array}$ & $\begin{array}{c}138.5 \pm 13.9 \\
(n=5)\end{array}$ & $\begin{array}{c}151.9 \pm 14.7 \\
(n=3)\end{array}$ \\
$\begin{array}{c}\text { Control } \\
\text { (without bOECs) }\end{array}$ & $\begin{array}{c}(n .0 \pm 6.2 \\
(n=25)\end{array}$ & $\begin{array}{c}137.6 \pm 7.1 \\
(n=31)\end{array}$ & $\begin{array}{c}137.1 \pm 16.6 \\
(n=7)\end{array}$ & $\begin{array}{c}152.0 \pm 10.8 \\
(n=12)\end{array}$ \\
\hline
\end{tabular}

bOECs: bovine oviduct epithelial cells; $n$ : number of embryos evaluated. Data are mean \pm SEM.

Table 4. Rates of development of bovine embryos after long-term co-culture in synthetic oviduct fluid (SOF) with $5 \%$ oestrous cow serum (OCS) (Expt 4)

\begin{tabular}{|c|c|c|c|c|c|c|}
\hline Culture system & $\begin{array}{c}\text { Number of } \\
\text { oocytes }\end{array}$ & $\begin{array}{c}\text { Cleavage rate } \\
\text { (day } 3)\end{array}$ & $\begin{array}{l}\text { Blastocysts } \\
\text { (day 8) }\end{array}$ & $\begin{array}{l}\text { Expanded } \\
\text { blastocysts }\end{array}$ & $\begin{array}{c}\text { Hatched } \\
\text { blastocysts }\end{array}$ & $\begin{array}{c}\text { Total rate of } \\
\text { blastocyst } \\
\text { development } \\
\text { (day 8) }\end{array}$ \\
\hline Co-culture (with bOECs) & 685 & ne & $10.7 \pm 1.4$ & $6.6 \pm 1.1$ & $3.1 \pm 0.7$ & $20.4 \pm 0.9$ \\
\hline Control (without bOECs) & 638 & ne & $9.8 \pm 1.4$ & $8.4 \pm 1.5$ & $6.6 \pm 2.0$ & $24.7 \pm 2.1$ \\
\hline
\end{tabular}

bOECs: bovine oviduct epithelial cells; ne: not evaluated.

Data are presented as mean \pm SEM of percentage of oocytes selected for IVF.

blastocysts, rates of development are not a sufficient indicator of embryo quality, as even morphologically intact class 1 embryos do not necessarily initiate pregnancies. Slotte et al. (1990) showed that metabolic defects caused low implantation rates of in vitro-produced embryos. As quantitative metabolic differences could serve as more relevant selection criteria, in the present study ATP content was evaluated in day 8 embryos. ATP production via oxidative phosphorylation is essential for bovine embryo development in vitro. However, transient inhibition of this process sometimes appears to be beneficial to embryo development (Thompson et al., 2000). Therefore, the lower ATP content in co-cultured embryos might not necessarily reflect a lower quality, as reduced ATP content was found in ex vivo embryos compared with IVP embryos (M. Stojkovic, unpublished) and did not hinder early embryonic development (Van Blerkom et al., 1995). Instead, the reduced ATP content may reflect higher energy demand of productive processes in co-cultured embryos (Leese, 1991). In the present study there was no difference in number of cells between the two groups (which would also result in a different ATP content), whereas Orsi et al. (2000) found fewer cells in co-cultured embryos. Nevertheless, ATP determination should be combined with measurement of ADP to evaluate the energy turnover via the ATP:ADP ratio (Slotte et al., 1990).

In addition, quantification of mRNA transcripts of selected developmentally relevant genes enables studies of the effects of bOECs on embryos. The Glut-1 gene was selected after it was shown that ex vivo embryos had higher Glut-1 expression compared with IVP embryos (Morita et al., 1994; Uechi et al., 1997; Wrenzycki et al., 1998).
Expression of Glut-1 was higher in co-cultured blastocysts when using 5\% OCS compared with cell-free culture; this finding was in accordance with the results of Wrenzycki et al. (2001), who detected an influence of different culture conditions on Glut- 1 expression. In the present study, the increased Glut-1 expression in co-cultured embryos was not found in later blastocyst stages, probably due to lower suitability of the oviductal feeder cells for these embryos, and therefore a sequential culture, for example a change from oviductal to uterine feeder cells, might be more appropriate.

Expression of HSP 70 might indicate suboptimal conditions, related to inadequate nutrient supply or oxidative stress, and was increased in co-cultured expanded blastocysts compared with controls, due to insufficient binding of free oxygen radicals normally mediated by bOEC co-culture (Thompson et al., 1990). HSP 70 expression might also resemble a reaction to other stressors such as enhanced toxic cell metabolites in co-culture (Bavister, 1995). This effect was reduced by the replacement of half the medium every second day in our experiments. However, HSP 70 expression does not necessarily indicate reduced vitality. It could also be a marker of embryonic cell functionality, as HSP is a chaperone that supports protein folding after de novo synthesis (Beckmann et al., 1992).

In medium supplemented with DCC-FCS, the higher expression of Glut-1 mRNA by co-cultured blastocysts indicates that the ability of this serum to maintain the differentiated status of bOECs also influences embryo development. However, higher Glut-1 mRNA expression was accompanied by a lower rate of blastocyst development and especially reduced hatching ability in DCC-FCS. 

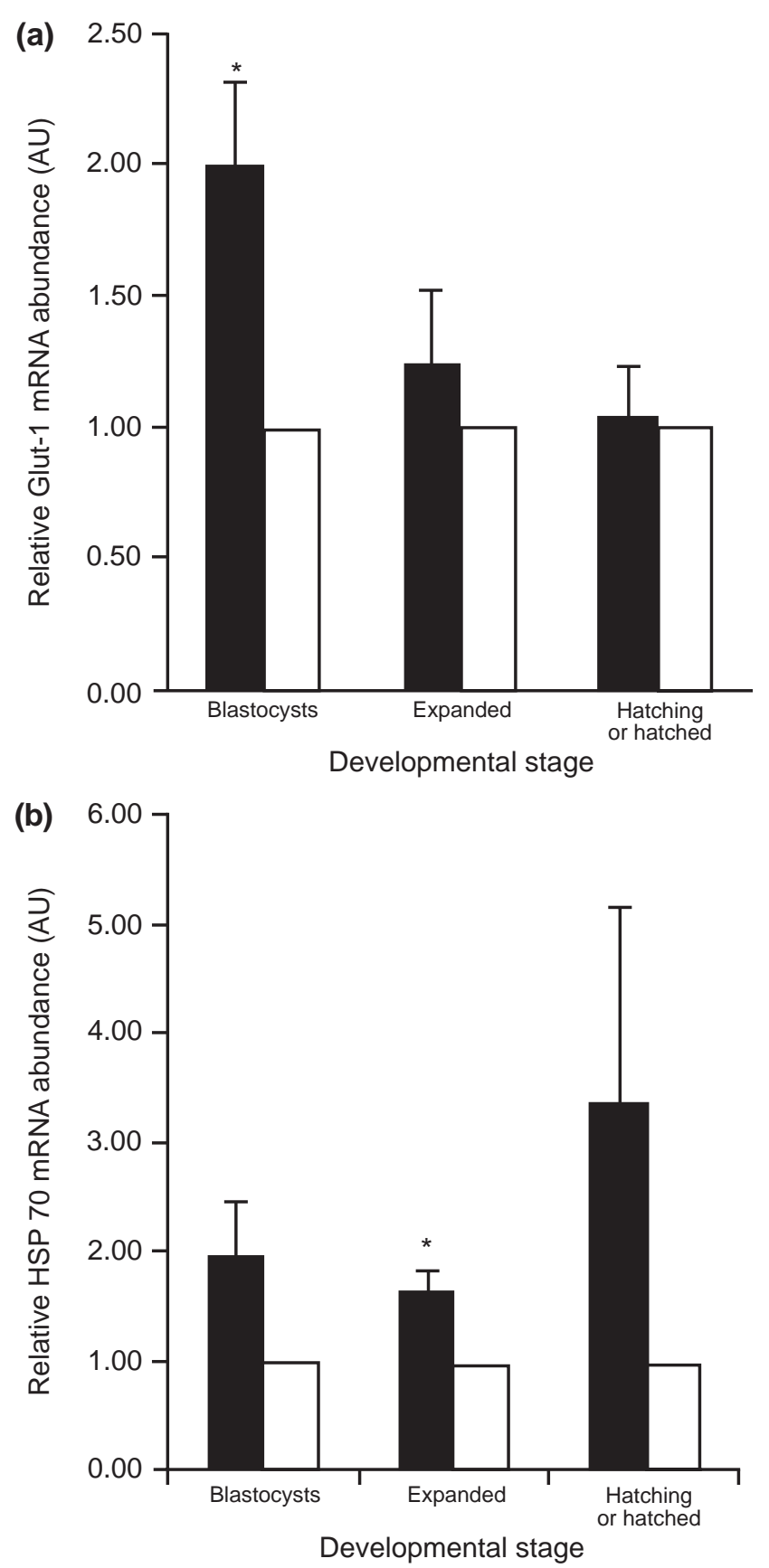

Fig. 4. RT-real-time-PCR quantification of expression of glucose transporter 1 (Glut-1) and heat shock protein 70 (HSP 70) mRNA in bovine blastocyst stages generated under different culture conditions (co-culture ( $\square$ ) versus control $(\square)$ in synthetic oviduct fluid (SOF) with $5 \%$ oestrous cow serum (OCS) (Expt 4). Relative (a) Glut-1 and (b) HSP 70 mRNA abundance of co-cultured embryos after normalization for GAPDH were calibrated on expression of control embryos (set to 1). Values are mean \pm SEM. Asterisk indicates differences in Glut-1 expression, although this effect was not significant $(P<0.08)$, and HSP 70 expression $(P<0.05)$ (one-sample $t$ test).

The latter effect might be due to a lack of specific serum factors that usually hinder the so-called 'zona hardening' (Schroeder et al., 1990) and to a reduced content of growth
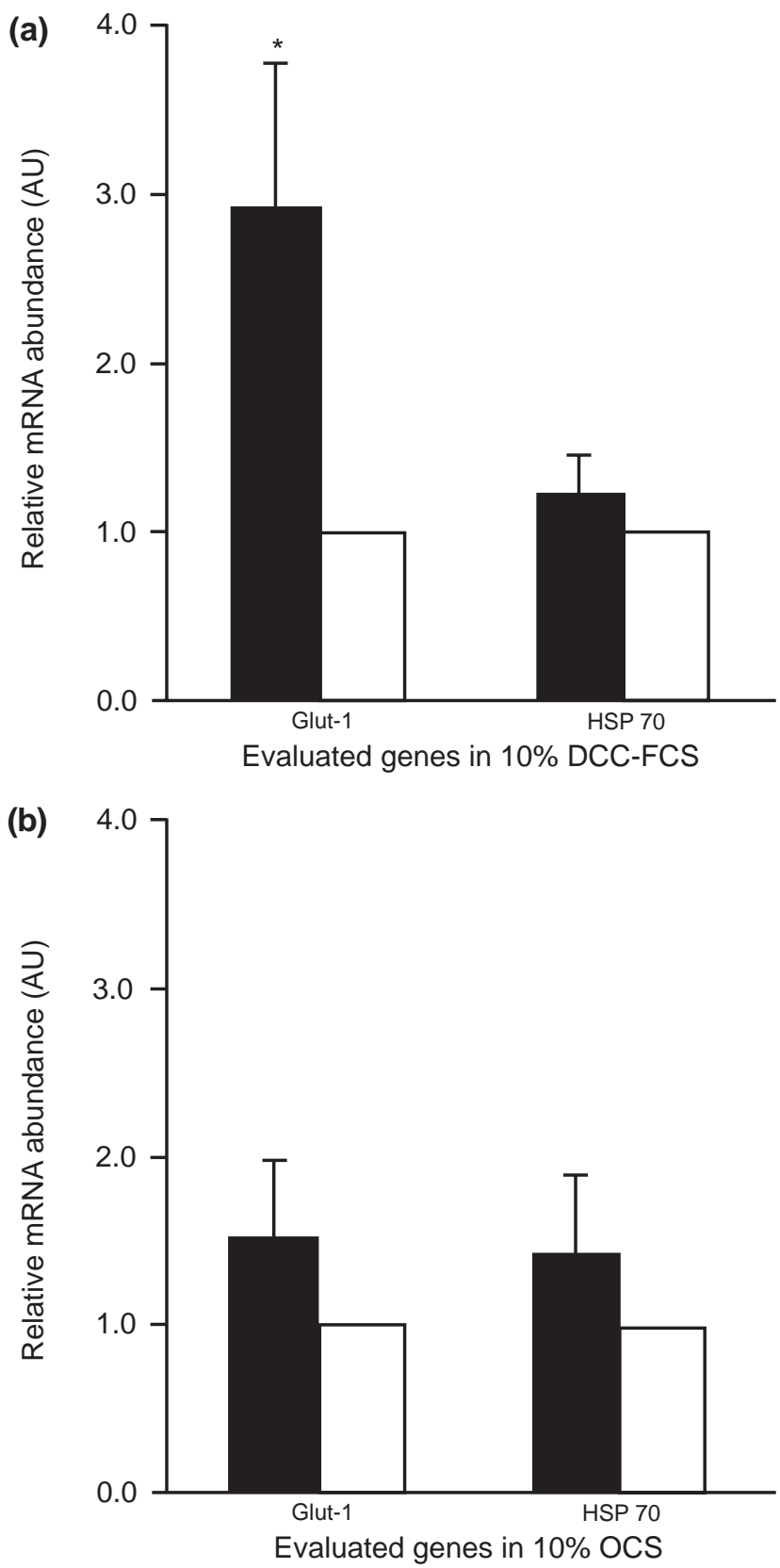

Fig. 5. RT-real-time-PCR to quantify mRNA expression of glucose transporter 1 (Glut-1) and heat shock protein 70 (HSP 70) in bovine blastocysts generated in co-culture ( $\square$ ) versus a cell-free system ( $\square$ ) with different sera (Expt 5). (a) Synthetic oviduct fluid (SOF) with $10 \%$ dextran-coated charcoal-treated fetal calf serum (DCC-FCS) increased Glut-1 mRNA content in co-cultured blastocysts, although the effect was not significant $(P<0.08$; indicated by asterisk). (b) SOF with $10 \%$ oestrous cow serum (OCS) did not cause significant differences in mRNA expression of Glut-1 and HSP 70, respectively, in different culture systems.

factors such as EGF that stimulate blastocyst development and hatching (Lonergan et al., 1996). Therefore, the results of the present study indicate that DCC-FCS is not optimal in a co-culture system to study embryo-maternal communication. However, Thompson et al. (1998) found similar rates of 
Table 5. Rates of development of bovine embryos after long-term co-culture in different sera (Expt 5)

\begin{tabular}{|c|c|c|c|c|c|c|}
\hline Culture system & $\begin{array}{l}\text { Number of } \\
\text { oocytes }\end{array}$ & $\begin{array}{l}\text { Cleavage rate } \\
\text { (day 3) }\end{array}$ & $\begin{array}{c}\text { Blastocysts } \\
\text { (day 8) }\end{array}$ & $\begin{array}{l}\text { Expanded } \\
\text { blastocysts }\end{array}$ & $\begin{array}{c}\text { Hatched } \\
\text { blastocysts }\end{array}$ & $\begin{array}{c}\text { Total rate of } \\
\text { blastocyst } \\
\text { development } \\
\text { (day 8) }\end{array}$ \\
\hline Co-culture, $10 \%(\mathrm{v} / \mathrm{v})$ OCS & 285 & ne & $27(9.5)$ & $13(4.6)$ & $21(7.4)^{\mathrm{c}}$ & $61(21.4)^{\mathrm{g}}$ \\
\hline Control, $10 \%(\mathrm{v} / \mathrm{v})$ OCS & 283 & ne & $28(9.9)$ & $22(7.8)$ & $38(13.4)^{d}$ & $88(31.1)^{\mathrm{h}}$ \\
\hline Total OCS & 568 & & $55(9.0)$ & $35(6.2)$ & $59(14.4)^{\mathrm{k}}$ & $149(26.2)^{\mathrm{m}}$ \\
\hline Co-culture, $10 \%(\mathrm{v} / \mathrm{v})$ DCC-FCS & 297 & ne & $37(12.5)$ & $14(4.7)^{\mathrm{a}}$ & $2(0.7)^{\mathrm{e}}$ & $53(17.8)^{\mathrm{i}}$ \\
\hline Control, $10 \%(\mathrm{v} / \mathrm{v})$ DCC-FCS & 271 & ne & $36(13.3)$ & $27(10.0)^{b}$ & $4(1.5)^{f}$ & $67(24.7)^{j}$ \\
\hline Total DCC-FCS & 568 & & $73(12.9)$ & $41(7.2)$ & $6(1.1)^{1}$ & $120(21.1)^{\mathrm{n}}$ \\
\hline
\end{tabular}

OCS: oestrous cow serum; DCC-FCS: dextran-coated charcoal-treated fetal calf serum; ne: not evaluated; Data are presented as total numbers and means of percentage (in brackets) of the oocytes selected for IVF.

Values with different superscripts within columns differ significantly (ab, cd, ij and ${ }^{\mathrm{mn}}$, all $P<0.05$; ${ }^{\mathrm{gh}}, P<0.01$; ${ }^{\mathrm{ce}}$, df and ${ }^{\mathrm{kl}}$, all $P<0.001$, chi-squared test).

development in the presence of DCC-FCS without cocultured cells compared with BSA-supplemented media.

The supportive influence of serum concentration on the functional status of bOECs became obvious when $5 \%$ OCS modulated the embryotrophic effect more efficiently resulting in a higher Glut-1 expression of co-cultured embryos compared with $10 \%$ OCS.

In the present study we have described a sensitive system to investigate embryo-maternal interactions, taking into account biologically relevant indicators (energy metabolism and expression of selected genes) of developmental capacity. Knowing that the requirements of embryos and oviductal cells per se are different, the results of this study showed that culture of bOECs in the embryo culture medium SOF with $5 \%$ OCS on cellulose nitrate matrix promotes differentiated growth and embryotrophic activity of feeder cells. Despite the lower rates of blastocyst development obtained in this system, which must be studied in more detail, for example by proving a suspected selection mechanism of more viable embryos by means of embryo transfer experiments or tolerance to cryopreservation, this co-culture system using bOECs in SOF plus OCS is a promising step forward in establishing an in vitro model to study embryo-maternal communication.

The authors gratefully acknowledge the excellent and skilful technical assistance of Christine Neumüller (Institute of Veterinary Anatomy II) with transmission electron microscopy and Heidrun Schöl (Institute for Comparative Tropical Medicine and Parasitology) with scanning electron microscopy. This study was supported by grants from the Deutsche Forschungsgemeinschaft (FOR 478/1) and the Bayerische Staatsministerium für Ernährung, Landwirtschaft und Forsten (A/99/8).

\section{References}

Barnes D and Sato G (1980) Methods for growth of cultured cells in serumfree medium Analytical Biochemistry 102 255-270

Bavister BD (1995) Culture of preimplantation embryos: facts and artefacts Human Reproduction Update 1/2 91-148
Beckmann RP, Lovett M and Welch WJ (1992) Examining the function and regulation of hsp 70 in cells subjected to metabolic stress Journal of Cell Biology 117 1137-1150

Buchner O and Wartenberg H (1997) Cytologie, Histologie und Mikroskopische Anatomie des Menschen, Verlag Hans Huber

Chatot CL, Lewis JL, Torres I and Ziomek CA (1989) Development of 1-cell embryos from different strains of mice in CZB medium Biology of Reproduction 42 432-440

Cox Cl and Leese HJ (1997) Retention of functional characteristics by bovine oviduct and uterine epithelia in vitro. Animal Reproduction Science $\mathbf{4 6}$ 169-178

Donati YRA, Slosman DO and Polla BS (1990) Oxidative injury and the heat shock response Biochemical Pharmacology 40 2571-2577

Edwards JL, Batt PA, Gandolfi F and Gardener DK (1997) Modifications made to culture medium by bovine oviduct epithelial cells: changes to carbohydrates stimulate bovine embryo development Molecular Reproduction and Development 46 146-154

Ellington JE (1991) The bovine oviduct and its role in reproduction: a review of the literature Cornell Veterinarian 81 313-328

Eyestone WH and First NL (1989) Co-culture of early cattle embryos to the blastocyst stage with oviductal tissue or in conditioned medium Journal of Reproduction and Fertility $\mathbf{8 5}$ 715-720

Eyestone WH and First NL (1991) Characterization of developmental arrest in early bovine embryos cultured in vitro. Theriogenology 35 613-625

Fortunati N, Fissore F, Fazzari A, Piovano F, Catalano MG, Becclus M, Berta $L$ and Fraira $\mathbf{R}$ (1999) Estradiol induction of cAMP in breast cancer cells is mediated by foetal calf serum (FCS) and sex hormone-binding globulin (SHBG) Journal of Steroid Biochemistry 70 73-80

Fukui Y, McGowan LT, James RW, Pugh PA and Tervit HR (1991) Factors affecting the in vitro development to blastocysts of bovine oocytes matured and fertilized in vitro. Journal of Reproduction and Fertility 92 125-131

Gandolfi F and Moor RM (1987) Stimulation of early embryonic development in the sheep by co-culture with oviduct epithelial cells Journal of Reproduction and Fertility 81 23-28

Gandolfi F, Tiziana AL, Richardson L, Brown CR and Moore R (1989) Characterisation of proteins secreted by sheep oviduct epithelial cells and their function in embryonic development Development 106 303-312

Gandolfi F, Brevini TAL, Modina S and Passoni L (1992) Early embryonic signals: embryo maternal interactions before implantation Animal Reproduction Science 28 269-276

Gardner DK, Lane M, Spitzer A and Batt P (1994) Enhanced rates of cleavage and development for sheep zygotes cultured to the blastocyst stage in vitro in the absence of serum and somatic cells: amino acids, vitamins, and culturing embryos in groups stimulate development Biology of Reproduction 50 390-400

Geneser F (1986) Textbook of Histology Munksgaard, Kopenhagen 
Gerena RL and Killian GJ (1990) Electrophoretic characterization of proteins in oviduct fluid of cows during the estrus cycle Journal of Experimental Zoology 256 113-120

Gordon I (1994) Laboratory Production of Cattle Embryos Cambridge University Press, Cambridge

Hunter RHF (1988) The Fallopian Tubes: their Role in Fertility and Infertility Springer Verlag, Berlin

Joshi MS (1995) Isolation, cell culture, and characterization of oviduct epithelial cells of the cow Microscopy Research Techniques 31 507-518

Karnovsky MJ (1965) A formaldehyde-glutaraldehyde fixative of high osmolarity for use in electron microscopy Journal of Cell Biology $\mathbf{2 7}$ 137A-138A

Kölle S, Stojkovic M, Prelle K, Waters M, Wolf E and Sinowatz S (2001) Growth hormone $(\mathrm{GH}) / \mathrm{GH}$ receptor expression and $\mathrm{GH}$-mediated effects during early bovine embryogenesis Biology of Reproduction 64 1826-1834

Krisher RL, Lane M and Bavister BD (1999) Developmental competence and metabolism of bovine embryos cultured in semi-defined culture media Biology of Reproduction 60 1345-1352

Lawitts JA and Biggers JD (1991) Optimization of mouse embryo culture media using simplex methods Journal of Reproduction and Fertility 91 543-556

Leese HJ (1988) The formation and function of oviductal fluid Journal of Reproduction and Fertility 82 843-856

Leese HJ (1991) Metabolism of the preimplantation mammalian embryo Oxford Review of Reproduction 13 35-72

Leese HJ (1995) Metabolic control during preimplantation mammalian development Human Reproduction Update 1 63-72

Leese HJ, Lonerghan J, Martin K and Hardy K (1993) Early human embryo metabolism Bioessays 15 259-264

Leese HJ, Donnay I and Thompson JG (1998) Human assisted conception: a cautionary tale. Lessons from domestic animals Human Reproduction 13 Supplement 4 184-202

Lonergan P, Carolan C, Van Langendonckt A, Donnay I, Khatir H and Mermillod P (1996) Role of epidermal growth factor in bovine oocyte maturation and preimplantation embryo development in vitro. Biology of Reproduction 54 1420-1429

Malayer JR, Hansen PJ and Buhi WC (1988) Secretion of proteins by cultured bovine oviducts collected from estrus through early diestrus Journal of Experimental Zoology 248 345-353

Morita Y, Tsutsumi O, Oka Y and Taketani Y (1994) Glucosetransporter Glut-1 mRNA expression in the ontogeny of glucose incorporation in mouse preimplantation embryos Biochemical and Biophysical Research Communications 199 1525-1531

Nayak RK and Ellington EF (1977) Ultrastructural and ultracytochemical cyclic changes in the bovine uterine tube (oviduct) epithelium American Journal of Veterinary Research 38 157-168

Niemann H and Wrenzycki C (2000) Alterations of expression of developmentally important genes in preimplantation bovine embryos by in vitro culture conditions: implications for subsequent development Theriogenology 53 21-34

Orsi NM, Leese HJ and Reischl J (2000) A novel somatic cell co-culture system for in vitro-produced bovine embryos Journal of Reproduction and Fertility Abstract Series $\mathbf{2 5}$ Abstract 206

Parrish JJ, Susko-Parrish JL, Leibfried-Rutledge ML, Crister ES, Eyestone WH and First NL (1986) Bovine in vitro fertilization with frozen-thawed semen Theriogenology 25 591-600

Pinyopummintr T and Bavister BD (1991) In vitro matured/in vitro fertilized bovine oocytes can develop into morulae/blastocysts in chemically defined, protein-free culture media Biology of Reproduction $\mathbf{4 5}$ 736-742

Prelle K, Stojkovic M, Boxhammer K, Motlik J, Ewald D, Arnold GJ and Wolf E (2001) Insulin-like growth factor I (IGF-I) and long R33 IGF-I differently affect development and messenger ribonucleic acid abundance for IGF-binding proteins and type I IGF receptors in in vitro produced bovine embryos Endocrinology 142 1309-1316

Reischl J, Prelle K, Schöl H, Neumüller C, Einspanier R, Sinowatz F and Wolf E (1999) Factors affecting proliferation and dedifferentiation of primary bovine oviduct epithelial cells in vitro. Cell and Tissue Research $296371-383$

Schroeder AC, Schultz RM, Kopf GS, Taylor FR, Becker RB and Eppig JJ (1990) Fetuin inhibits zona pellucida hardening and conversion of ZP2 to ZP2f during spontaneous mouse oocyte maturation in vitro in the absence of serum Biology Reproduction 43 891-897

Sendai Y, Abe H, Kikuchi M, Satho T and Hoshi H (1994) Purification and molecular cloning of bovine oviduct-specific glycoprotein Biology of Reproduction $\mathbf{5 0}$ 927-934

Slotte H, Gustafson O, Nylund L and Pousette A (1990) ATP and ADP in human pre-embryos Human Reproduction 5 319-321

Staros AL and Killian GJ (1998) In vitro association of six oviductal fluid proteins with the bovine zona pellucida Journal of Reproduction and Fertility 112 131-137

Stojkovic M, Wolf E, Büttner M, Berg U, Charpigny G, Schmitt A and Brem G (1995) Secretion of biologically active interferon tau by in vitroderived bovine trophoblastic tissue Biology of Reproduction $\mathbf{5 3}$ 1500-1507

Stojkovic M, Westesen K, Zakhatchenko V, Stojkovic P, Boxhammer K and Wolf E (1999) Coenzyme Q10 in submicron-sized dispersion improves development, hatching, cell proliferation, and adenosine triphosphate content of in vitro-produced bovine embryos Biology of Reproduction $61541-547$

Tervit HR, Whittingham DG and Rowson LEA (1972) Successful culture in vitro of sheep and cattle ova Journal of Reproduction and Fertility $\mathbf{3 0}$ 493-497

Thibodeaux JK, Ménézo Y, Roussel JD, Hansel W, Goodeaux LL, Thompson DL, Jr and Godke RA (1992) Coculture of in vitro fertilized bovine embryos with oviductal epithelial cells originating from different stages of the estrous cycle Journal of Dairy Science 75 1448-1455

Thompson JG (1996) Defining the requirements for bovine embryo culture Theriogenology 45 27-40

Thompson JG (2000) In vitro culture and embryo metabolism of cattle and sheep embryos - a decade of achievement Animal Reproduction Science 60 263-275

Thompson JGE, Simpson AC, Pugh PA, Donelly PE and Tervit HR (1990) Effect of oxygen concentration on in vitro development of preimplantation sheep and cattle embryos Journal of Reproduction and Fertility $\mathbf{8 9}$ 573-578

Thompson JG, Allen NW, McGowan LT, Bell AC, Lambert MG and Tervit HR (1998) Effect of delayed supplementation of fetal calf serum to culture medium on bovine embryo development in vitro and following transfer Theriogenology 49 1239-1249

Thompson JG, McNaughton C, Gasparrini B, McGowan LT and Tervit HR (2000) Effect of inhibitors and uncouplers of oxidative phosphorylation during compaction and blastulation of bovine embryos cultured in vitro. Journal of Reproduction and Fertility 118 47-55

Uechi H, Tsutsumi O, Morita Y and Taketani Y (1997) Cryopreservation of mouse embryos affects later embryonic development possibly through reduced expression of the glucose transporter Glut-1 Molecular Reproduction and Development 48 496-500

Van Blerkom J, Davis PW and Lee J (1995) ATP content of human oocytes and developmental potential and outcome after in vitro fertilization and embryo transfer Human Reproduction 10 415-424

Wegner CC and Killian GJ (1992) Origin of oestrus-associated glycoproteins in bovine oviductal fluid Journal of Reproduction and Fertility 95 841-852

Witkowska E (1979) Reactivity of the epithelial cells of bovine oviduct in vitro on the exogenic gonadotropic and steroid hormones. Part I: the effect of gonadotropic and steroid hormones on the amount of lipids and activity of dehydrogenase. Part II: the effect of gonadotropic hormones on the amount of glycogen and of acid and alkaline phosphatases Folia Histochemistry and Cytochemistry 17 225-250

Wobus AM, Guan K, Yang H-T and Boheler KR (2001) Embryonic stem cells as a model to study cardiac, skeletal muscle, and vascular smooth muscle cell differentiation. In Methods in Molecular Biology 185 Embryonic Stem Cells: Methods and Protocols pp 127-156 Ed. K Turksen. Humana Press, Totowa

Wrenzycki C, Herrmann D, Carnwath JW and Niemann H (1998) Expression of RNA from developmentally important genes in preimplan- 
tation bovine embryos produced in TCM supplemented with BSA Journal of Reproduction and Fertility 112 387-398

Wrenzycki C, Herrmann D, Carnwath JW and Niemann H (1999) Alterations in the relative abundance of gene transcripts in preimplantation bovine embryos cultured in medium supplemented with either serum or PVA Molecular Reproduction and Development 53 8-18

Wrenzycki C, Hermann D, Keskintepe L, Martins A, Jr, Sirisathien S, Brackett B and Niemann H (2001) Effects of culture systems and protein supplementation on mRNA expression in pre-implantation bovine embryos Human Reproduction 16 893-901
Wright RW and Bondioli KR (1981) Aspects of in vitro fertilization and embryo culture in domestic animals Journal of Animal Science 53 $702-728$

Received 22 March 2002

First decision 9 April 2002.

Revised manuscript received 23 May 2002.

Accepted 27 June 2002. 